\title{
Novel ferrocenyl derivatives exert anti-cancer effect in human lung cancer cells in vitro via inducing $\mathbf{G}_{1^{-}}$ phase arrest and senescence
}

\author{
Ying $\mathrm{LI}^{1, \#}$, Han-lin MA', \#, Lei HAN ${ }^{1}$, Wei-yong $\mathrm{LIU}^{2}$, Bao-xiang ZHAO ${ }^{2, *}$, Shang-li ZHANG ${ }^{1}$, Jun-ying MIAO ${ }^{1, *}$ \\ ${ }^{1}$ Shandong Provincial Key Laboratory of Animal Cells and Developmental Biology, Institute of Developmental Biology, School of Life \\ Science, Shandong University, Ji-nan 250100, China; ${ }^{2}$ School of Chemistry and Chemical Engineering, Shandong University, Ji-nan \\ 250100, China
}

Aim: To investigate the effects of 7 novel 1-ferrocenyl-2-(5-phenyl-1H-1,2,4-triazol-3-ylthio) ethanone derivatives on human lung cancer cells in vitro and to determine the mechanisms of action.

Methods: A549 human lung cancer cells were examined. Cell viability was analyzed with MTT assay. Cell apoptosis and senescence were examined using Hoechst 33258 and senescence-associated- $\beta$-galactosidase (SA- $\beta$-gal) staining, respectively. LDH release was measured using a detection kit. Cell cycle was analyzed using a flow cytometer. Intracellular ROS level was measured with the 2',7'dichlorodihydrofluorescein probe. Phosphorylation of p38 was determined using Western blot.

Results: Compounds 5b, 5d, and 5 e (40 and $80 \mu \mathrm{mol} / \mathrm{L}$ ) caused significant decrease of A549 cell viability, while other 4 compounds had no effect on the cells. Compounds $5 \mathrm{~b}, 5 \mathrm{~d}$, and $5 \mathrm{e}(80 \mu \mathrm{mol} / \mathrm{L})$ induced $\mathrm{G}_{1}$-phase arrest (increased the $\mathrm{G}_{1}$ population by $22.6 \%$, $24.23 \%$, and $26.53 \%$, respectively), and markedly increased SA- $\beta$-gal-positive cells. However, the compounds did not cause nuclear DNA fragmentation and chromatin condensation in A549 cells. Nor did they affect the release of LDH from the cells. The compounds significantly elevated the intracellular ROS level, decreased the mitochondrial membrane potential, and increased p38 phosphorylation in the cells. In the presence of the antioxidant and free radical scavenger $N$-acetyl- $L$-cysteine (10 mmol/L), above effects of compounds $5 b, 5 d$, and $5 e$ were abolished.

Conclusion: The compounds 5b, 5d, and 5e cause neither apoptosis nor necrosis of A549 cells, but exert anti-cancer effect via inducing $\mathrm{G}_{1}$-phase arrest and senescence through ROS/p38 MAP-kinase pathway.

Keywords: human lung cancer; ferrocene; triazoles; cell cycle arrest; apoptosis; senescence; senescence-associated- $\beta$-galactosidase; ROS; p38

Acta Pharmacologica Sinica (2013) 34: 960-968; doi: 10.1038/aps.2013.19; published online 6 May 2013

\section{Introduction}

Lung cancer is not only one of the most common malignant human tumors but also a leading cause of death worldwide ${ }^{[1]}$. There are two major types of lung cancer, small cell lung cancer (SCLC) and non-small cell lung cancer (NSCLC). According to American Cancer Society (ACS) statistics, NSCLC accounts for approximately $85 \%$ to $90 \%$ of lung cancer cases. NSCLC consists of three subtypes, squamous cell carcinoma, adenocarcinoma and large-cell carcinoma; however, approximately $40 \%$ of lung cancers are adenocarcinomas. A549 is a

\footnotetext{
\# These authors contributed equally to this work.

* To whom correspondence should be addressed.

E-mail miaojy@sdu.edu.cn (Jun-ying MIAO); bxzhao@sdu.edu.cn (Bao-xiang ZHAO)

Received 2012-11-05 Accepted 2013-02-17
}

lung adenocarcinoma cell line that has been well characterized and is frequently used for molecular cancer biology research. Uncontrolled proliferation is a key feature of cancer cells, and therefore, inhibition of proliferative pathways is an effective approach for cancer therapy ${ }^{[2-4]}$.

1,2,4-Triazoles and their condensed derivatives have been investigated due to their wide range of bioactivities, including antimicrobial $^{[5-8]}$, analgesic-anti-inflammatory ${ }^{[9]}$, antifungal ${ }^{[10]}$, herbicidal $^{[11]}$, insecticidal activity ${ }^{[12]}$, anticancer ${ }^{[13,14]}$, and antigenotoxic activity ${ }^{[15]}$. It is known that the incorporation of a ferrocene fragment into a molecule of an organic compound often produces unexpected biological activity, likely due to different membrane permeation properties and anomalous metabolism. Many ferrocenyl compounds display interesting cytotoxic, anti-tumor, antimalarial, antifungal and DNAcleaving activities ${ }^{[16,17]}$. Recently, several new ferrocenyl- 
substituted heterocyclic compounds have been reported to be potential pharmaceuticals ${ }^{[18-22]}$. To find more bioactive molecules, including effective anti-cancer reagents, we previously reported the synthesis of novel 1-ferrocenyl-2-(5-phenyl$1 \mathrm{H}$-1,2,4-triazol-3-ylthio)ethanone derivatives and performed X-ray crystal structure and optical property analyses of these compounds $^{[23]}$. The structures of these derivatives $(5 \mathrm{a}-\mathrm{g})$ are shown in Figure 1. However, the bioactivity of these compounds was unknown.

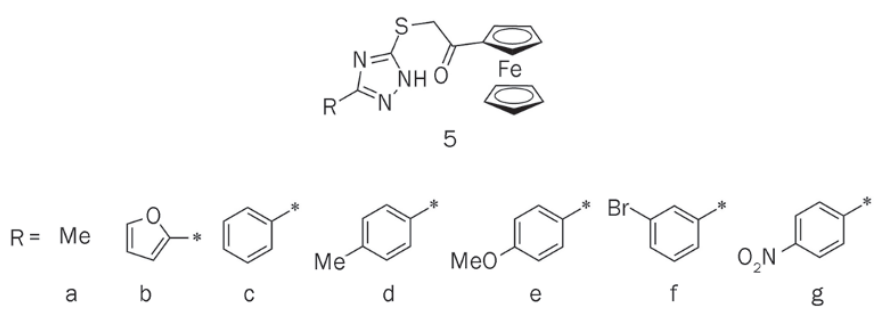

Figure 1. Structures of compounds $5 a-g$.

As part of the ongoing study in our laboratory on the discovery and development of anticancer reagents ${ }^{[24-27]}$, we are interested in studying the anti-cancer mechanisms of small molecules. A better understanding of the molecular mechanisms of cytotoxic drug action has shed light on lung cancer treatments. Novel agents that target specific intracellular pathways related to distinct properties of cancer cells continue to be developed. In addition, the study of the molecular mechanisms of mitochondrial damaging agents in lung cancer cells will aid in the development of drugs related to mitochondrial damage for the treatment of lung cancer. The production of reactive oxygen species (ROS) by the mitochondria is considered to be a major factor in the process of senescence ${ }^{[28]}$.

Cellular senescence is broadly defined as permanent and irreversible growth arrest, and it is characterized by a specific cellular morphology and gene expression pattern ${ }^{[29]}$. Senescence, as a stress response, is a potent anti-cancer program. The signaling events underlying senescence have been involved in invasion, metastasis, and proliferation, all of which are directly linked to tumorigenesis. Therefore, cancer cell senescence has become a new frontier for drug development. Herein, we report the growth inhibitory effect of 1 -ferrocenyl2-(5-phenyl-1H-1,2,4-triazol-3-ylthio)ethanone derivatives in A549 cells via the induction of senescence. In this study, we found that ferrocenyl derivatives induced senescence in A549 NSCLC cells by reducing mitochondrial membrane potential and elevating ROS levels. Furthermore, ferrocenyl derivatives increased intracellular ROS and induced senescence in A549 cells via the p38 MAP-kinase signaling pathway.

\section{Materials and methods}

\section{Reagents and chemicals}

RPMI-1640 was purchased from Gibco Co (Carlsbad, CA, USA). Bovine calf serum was purchased from Beijing Ding-
Guo Biotechnology Co(Beijing, China). DMSO was supplied by Shanghai Sangon Biological Engineering Technology and Services Company (Shanghai, China). N-acetyl-L-cysteine was obtained from Sigma-Aldrich (St Louis, MO, USA).

\section{Cell culture}

A549 lung cancer cells were cultured in RPMI-1640 medium supplemented with $10 \%(v / v)$ bovine calf serum and $80 \mathrm{U} / \mathrm{mL}$ penicillin/streptomycin at $37^{\circ} \mathrm{C}$ in $5 \% \mathrm{CO}_{2}$. The cells were seeded in 96-well plates or the indicated dishes at a density of 6250 cells $/ \mathrm{cm}^{2}$.

\section{Cell viability assay}

As previously reported, cells were seeded in 96-well plates and treated with compounds $5 \mathrm{~b}, 5 \mathrm{~d}$, and $5 \mathrm{e}(80 \mu \mathrm{mol} / \mathrm{L})$ for $48 \mathrm{~h}$, respectively. Cell viability was determined by MTT (3-(4,5-dimethylthiazol-2-yl)-2,5-diphenyltetrazolium) assays, according to the method of Price and McMillan ${ }^{[30]}$. Light absorption was measured at $570 \mathrm{~nm}$ using a Spectra MAX 190 microplate spectrophotometer (GMI Co, USA).

\section{Flow cytometric analysis of cell cycle distribution}

Cells were treated with compounds $5 \mathrm{~b}, 5 \mathrm{~d}$, and $5 \mathrm{e}(80 \mu \mathrm{mol} / \mathrm{L})$ for $48 \mathrm{~h}$, respectively. Then, the cells were harvested, fixed with $70 \%$ ethanol, and stained with $50 \mu \mathrm{g} / \mathrm{mL}$ propidium iodide (PI) containing $10 \mu \mathrm{g} / \mathrm{mL}$ RNase A at $4{ }^{\circ} \mathrm{C}$ for $1 \mathrm{~h}$. The stained cells were analyzed using a FACSCalibur flow cytometer (BD Bioscience, USA). The cell cycle distribution was analyzed with ModiFit software (BD Bioscience, USA).

\section{Hoechst 33258 staining}

Cells were plated in 24 -well plates at a density of $1.25 \times 10^{4}$ cells $/ \mathrm{cm}^{2} 24 \mathrm{~h}$ before treatment with $0.1 \%$ DMSO $(v / v$, as a control) or compounds $5 \mathrm{~b}, 5 \mathrm{~d}$, and $5 \mathrm{e}(80 \mu \mathrm{mol} / \mathrm{L})$, respectively. Forty-eight hours after treatment, the living cells were stained with $10 \mu \mathrm{g} / \mathrm{mL}$ Hoechst 33258 for $20 \mathrm{~min}$. The cells were gently washed with PBS and photographed using an Olympus (Japan) BH-2 fluorescence microscope.

\section{Senescence-associated-beta-galactosidase (SA- $\beta$-gal) staining}

A549 cell senescence was identified by senescence-associated $\beta$-gal staining ${ }^{[31]}$. After $60 \mathrm{~h}$ treatment with $5 \mathrm{~b}, 5 \mathrm{~d}$, and $5 \mathrm{e}$ $(80 \mu \mathrm{mol} / \mathrm{L})$, cells were rinsed twice with PBS, fixed for $5 \mathrm{~min}$ in a solution containing formaldehyde and glutaraldehyde, and then rinsed with PBS. One milliliter of staining solution was added to each well, and the cells were incubated overnight at $37^{\circ} \mathrm{C}$. The cells were rinsed with PBS and observed by phase-contrast microscopy. The percentage of positively stained cells was calculated by counting cells in random visual fields, and at least 2000 cells were counted for each sample.

\section{LDH assay}

Cell culture medium was collected after $48 \mathrm{~h}$ treatment with $0.1 \%$ DMSO (control) or compounds $5 \mathrm{~b}, 5 \mathrm{~d}$, and $5 \mathrm{e}(80$ $\mu \mathrm{mol} / \mathrm{L})$. The $\mathrm{LDH}$ assay was performed using a Lactate Dehydrogenase (LDH) kit (Nanjing Jiancheng Co, China), 
according to the manufacturer's instructions.

\section{Intracellular ROS assay}

The levels of intracellular ROS were detected in cells treated with or without compounds $5 \mathrm{~b}, 5 \mathrm{~d}$, and $5 \mathrm{e}(80 \mu \mathrm{mol} / \mathrm{L})$ using a fluorescent probe, $2^{\prime}, 7^{\prime}$-dichlorodihydrofluorescin (DCHF, Sigma, USA), which can be oxidized into fluorescent $2^{\prime}, 7^{\prime}$ dichlorofluorescin (DCF) by intracellular ROS. Fluorescence was monitored by laser scanning confocal microscopy (Leica, Germany). The amount of ROS was quantified as the relative fluorescence intensity of DCHF per cell in the scanned area.

\section{Mitochondrial membrane potential (MMP) measurement}

Mitochondrial membrane potential was estimated by measuring the fluorescence of JC-1 aggregates, which are formed as a function of inner mitochondrial membrane potential ${ }^{[32,33]}$. The formation of JC-1 aggregates and their fluorescence directly correlate with an increase in membrane potential. After treatment with $0.1 \%$ DMSO (control) or compounds $5 \mathrm{~b}, 5 \mathrm{~d}$, and $5 \mathrm{e}(80 \mu \mathrm{mol} / \mathrm{L})$, the cells were plated in 24-well plates and incubated with $4 \mu \mathrm{g} / \mathrm{mL}$ JC-1 for $20 \mathrm{~min}$ at $37^{\circ} \mathrm{C}$ in a humidified incubator. Then, the cells were washed 2 times with PBS, and the fluorescence (red fluorescence: excitation, $543 \mathrm{~nm}$ and emission, $600 \mathrm{~nm}$; green fluorescence: excitation, $488 \mathrm{~nm}$ and emission, $535 \mathrm{~nm}$ ) ratio was detected. We randomly selected each region of interest (ROI) and zoomed in on the same frames. The data are presented as the relative ratio of red/green fluorescence intensity values.

\section{Western blot analysis}

Western blotting and quantification of the relative protein were performed as described previously ${ }^{[34]}$. Briefly, after treatment with the indicated compounds, cells were lysed in protein lysis buffer [ $1 \% \mathrm{SDS}, 25 \mathrm{mmol} / \mathrm{L}$ Tris- $\mathrm{HCl}(\mathrm{pH} 7.5)$, $4 \mathrm{mmol} / \mathrm{L}$ EDTA, $100 \mathrm{mmol} / \mathrm{L} \mathrm{NaCl}, 1 \mathrm{mmol} / \mathrm{L}$ PMSF, 10 $\mathrm{mg} / \mathrm{mL}$ leupeptin and $10 \mathrm{mg} / \mathrm{mL}$ soybean trypsin inhibitor]. The protein concentration of the lysates was determined using the Coomassie brilliant blue protein assay. A549 cell protein extracts $(20 \mu \mathrm{g})$ were loaded on $9 \%$ SDS polyacrylamide gels, subjected to electrophoresis, and transferred to a nitrocellulose membrane. The membranes were incubated with anti-p38 (Cell Signaling, Beverly, MA, USA) or anti-GAPDH antibodies (Santa Cruz Biotechnology, Dallas, TX, USA) (1:1000 dilution), and the indicated proteins were detected with a horseradish peroxidase-conjugated IgG. The band intensity was quantified using Quantity One software (Bio-Rad, USA) and normalized to GAPDH levels.

\section{Statistical analyses}

The data are presented as the mean \pm SEM and were analyzed by SPSS (Statistical Package for the Social Sciences) software. The figures were processed with Adobe Photoshop software. The mean values were derived from at least 3 independent experiments. Differences with a $P<0.05$ were considered statistically significant.

\section{Results}

Compounds 5b, 5d, and 5e inhibited A549 lung cancer cell proliferation

To examine the anti-cancer activity of 1-ferrocenyl-2-(5-phenyl-1H-1,2,4-triazol-3-ylthio)ethanone derivatives, we monitored the morphological changes of A549 cells after treatment with compounds 5a-g using a phase contrast microscope. We observed no morphological changes, even after treatment with an $80 \mu \mathrm{mol} / \mathrm{L}$ dose of each compound for $48 \mathrm{~h}$. However, cell viability was decreased in response to compounds $5 b, 5 d$, and $5 e$ (Figure 2A). The results of the MTT assay revealed that compounds $5 \mathrm{~b}, 5 \mathrm{~d}$, and $5 \mathrm{e}$ inhibited the growth of A549 cells

A
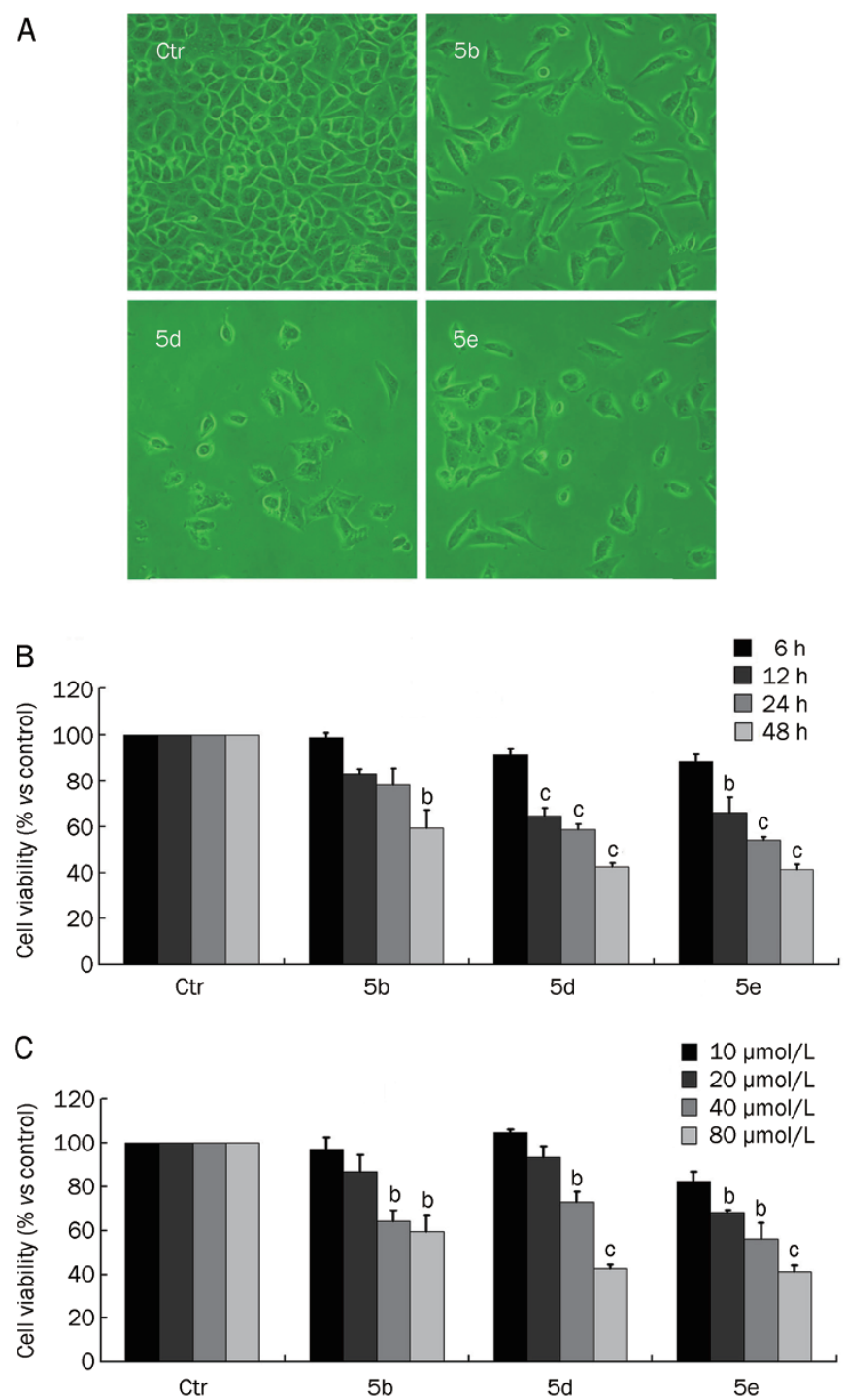

Figure 2. (A) Morphology of A549 cells after treatment with compounds $5 \mathrm{~b}, 5 \mathrm{~d}$, and $5 \mathrm{e}(80 \mu \mathrm{mol} / \mathrm{L})$ for $48 \mathrm{~h}$, as obtained using a phase contrast microscope $(\times 200)$. (B) Viability of A549 cells after treatment with compounds $5 b, 5 d$ and $5 e(80 \mu \mathrm{mol} / \mathrm{L})$ for various times $(6,12,24$, and $48 \mathrm{~h}$ ). (C) Viability of A549 cells after treatment with $10,20,40$, and $80 \mu \mathrm{mol} / \mathrm{L}$ compounds $5 \mathrm{~b}, 5 \mathrm{~d}, 5 \mathrm{e}$ for $48 \mathrm{~h}\left({ }^{b} P<0.05,{ }^{c} P<0.01\right.$ vs control group; $n=3$ ). 
(Figure 2B). None of the other compounds showed an effect on A549 cell growth (data not shown).

\section{Compounds $5 b, 5 d$, and $5 e$ induced $\mathrm{G}_{1}$-phase arrest}

It is well known that the regulation of critical events in the cell cycle may be a useful strategy for anti-tumor therapy ${ }^{[35,36]}$. We previously reported that novel ferrocenyl pyrazolo[1,5-a] pyrazin-4(5H)-one derivatives possess significant anti-tumor activity and induce cell cycle arrest ${ }^{[37]}$. To detect whether compounds 5b, 5d, and 5e induce cell cycle arrest in A549 cells, we performed flow cytometric analysis. Treatment with compounds $5 \mathrm{~b}, 5 \mathrm{~d}$, and $5 \mathrm{e}(80 \mu \mathrm{mol} / \mathrm{L})$ for $48 \mathrm{~h}$ induced A549 $\mathrm{G}_{1}$-phase arrest in A549 cells (Figure 3). After treatment with compounds $5 \mathrm{~b}, 5 \mathrm{~d}$, and $5 \mathrm{e}(80 \mu \mathrm{mol} / \mathrm{L})$ for $48 \mathrm{~h}$, the $\mathrm{G}_{1}$ populations were enhanced by $22.6 \%, 24.23 \%$, and $26.53 \%$ compared to the control, respectively. This increase in the $\mathrm{G}_{1}$-phase cell population was accompanied by a decrease in the $S$ - and $\mathrm{G}_{2}$-phase cell populations.

Compounds 5b, 5d, and 5e induced senescence in A549 lung cancer cells

To detect whether compounds $5 \mathrm{~b}, 5 \mathrm{~d}$, and 5e caused apoptosis, necrosis or senescence in A549 cells, we performed Hoechst 33258 staining, LDH assays and senescence-associated-beta-galactosidase (SA- $\beta$-Gal) staining, respectively. DNA fragmentation, chromatin condensation, cell shrinkage, and membrane blebbing are well-known characteristics of apoptotic cells. Hoechst 33258 staining revealed that nuclear DNA fragmentation and chromatin condensation did not occur in the cells treated with $5 b, 5 d$, and $5 e(80 \mu \mathrm{mol} / \mathrm{L})$ for
$48 \mathrm{~h}$ (Figure 4A). The LDH assay showed no significant difference $(P>0.05)$ in the LDH level between cells in the control group and cells treated with compounds $5 \mathrm{~b}, 5 \mathrm{~d}$, and $5 \mathrm{e}(80$ $\mu \mathrm{mol} / \mathrm{L}$ ) for $48 \mathrm{~h}$ (Figure $4 \mathrm{C}$ ). Furthermore, these compounds did not cause necrosis in A549 cells. The classical method for detecting senescence is to test for SA- $\beta$-Gal activity in cells using the substrate, $X$-Gal (5-bromo-4-chloro-3-indoly- $\beta$-D-

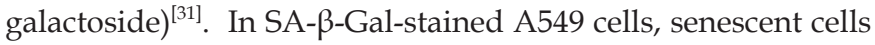
were stained blue. Compounds $5 \mathrm{~b}, 5 \mathrm{~d}$, and $5 \mathrm{e}(80 \mu \mathrm{mol} / \mathrm{L})$ significantly increased the quantity of SA- $\beta$-gal positive cells compared to controls, as shown in Figure 4B and 4D $(P<0.001)$.

Compounds 5b, 5d, and 5e promoted p38 phosphorylation, elevated ROS, and decreased MMP expression

Reactive oxygen species (ROS) are a natural byproduct of the normal metabolism of oxygen, and they play important roles in the signaling of cellular senescence. The main metabolic source of ROS is the mitochondrial electron-transport chain, and the accumulation of intracellular ROS can cause mitochondrial dysfunction, resulting in reduced mitochondrial membrane potential (MMP). To understand the possible mechanisms by which compounds $5 \mathrm{~b}, 5 \mathrm{~d}$ and $5 \mathrm{e}$ induce senescence in A549 cells, we measured the levels of intracellular ROS. Compounds $5 \mathrm{~b}, 5 \mathrm{~d}$, and $5 \mathrm{e}(80 \mu \mathrm{mol} / \mathrm{L})$ significantly increased the levels of ROS in A549 cells (Figure 5A and 5C). To further understand the effect of intracellular ROS accumulation, we measured the MMP level, which is also a main characteristic of cellular senescence. Upon treatment with compounds $5 \mathrm{~b}$, $5 \mathrm{~d}$, and $5 \mathrm{e}(80 \mu \mathrm{mol} / \mathrm{L})$ for $48 \mathrm{~h}$, the MMP in A549 cells was dramatically reduced compared to the control group (Figure
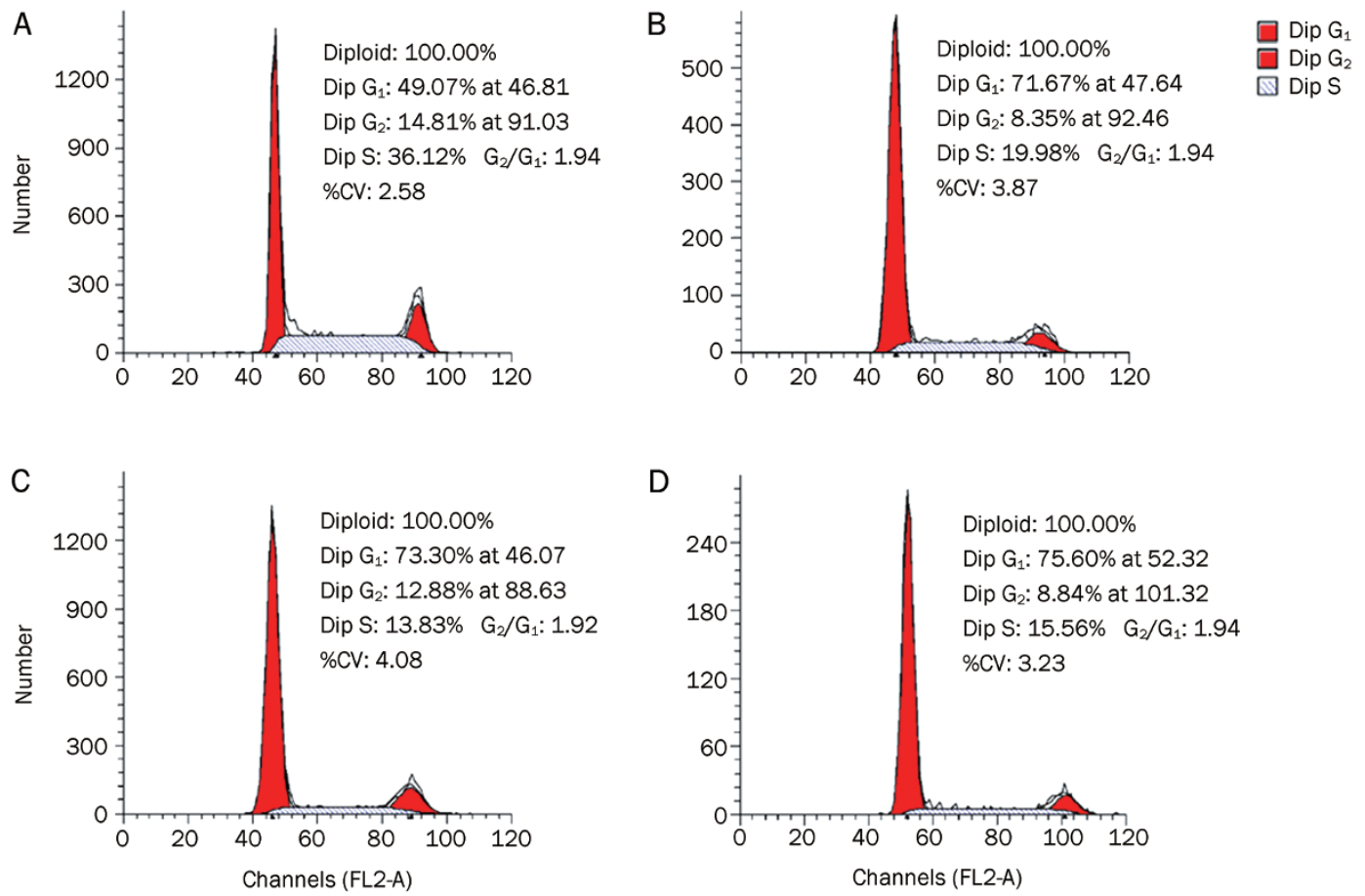

Figure 3. Effects of compounds $5 \mathrm{~b}, 5 \mathrm{~d}$, and $5 \mathrm{e}$ on the cell cycle distribution of $\mathrm{A} 549$ cells. Cells were exposed to compounds $5 \mathrm{~b}, 5 \mathrm{~d}$, and $5 \mathrm{e}(80 \mu \mathrm{mol} / \mathrm{L})$ for $48 \mathrm{~h}$. The values are expressed as the percentage of the cell population in the $\mathrm{G}_{1}{ }^{-}, \mathrm{S}-$, and $\mathrm{G}_{2}-$ phases of the cell cycle. A, Control; B, 5b; C, $5 \mathrm{~d}$; D, $5 \mathrm{e}$. 

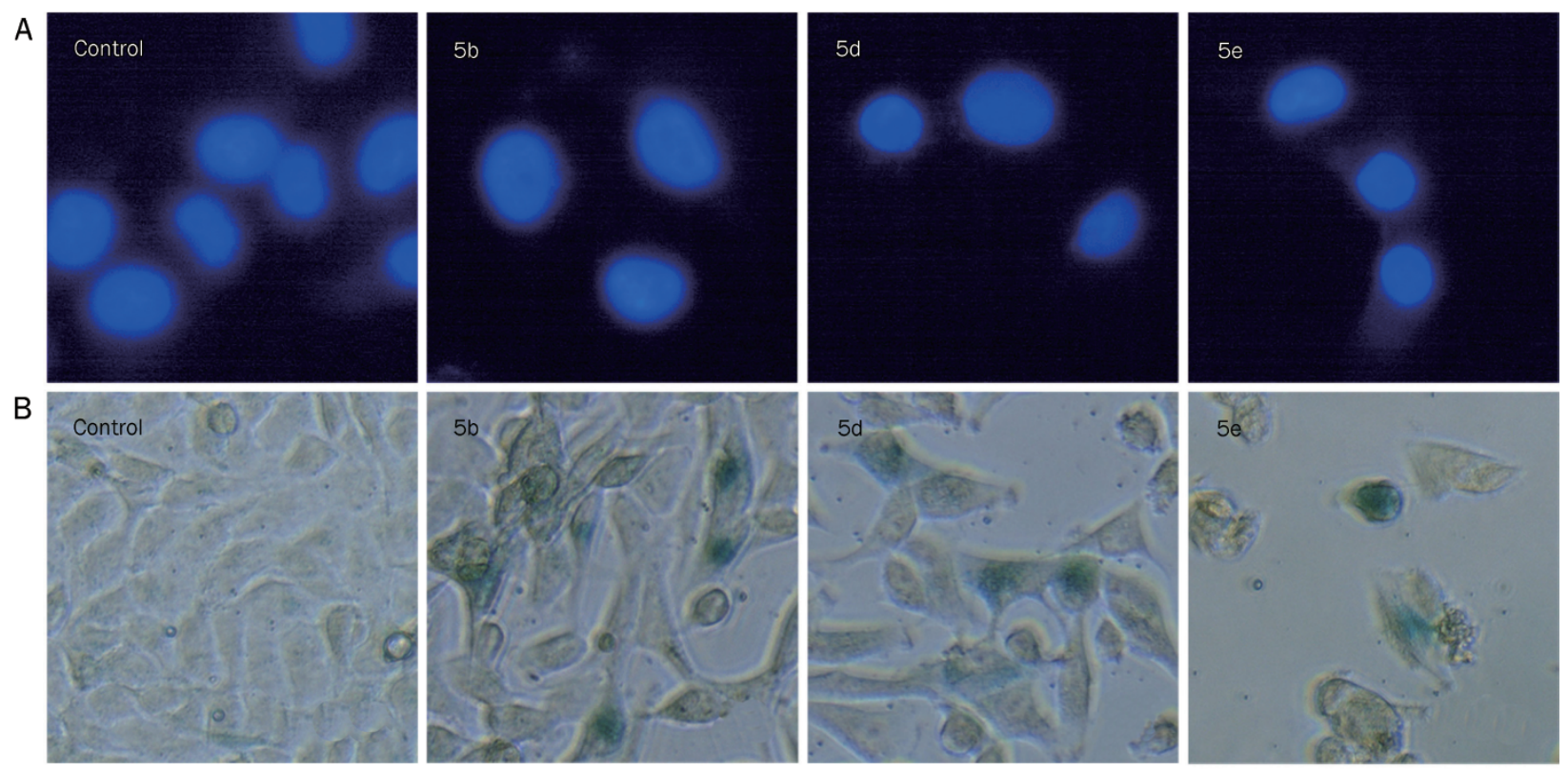

C
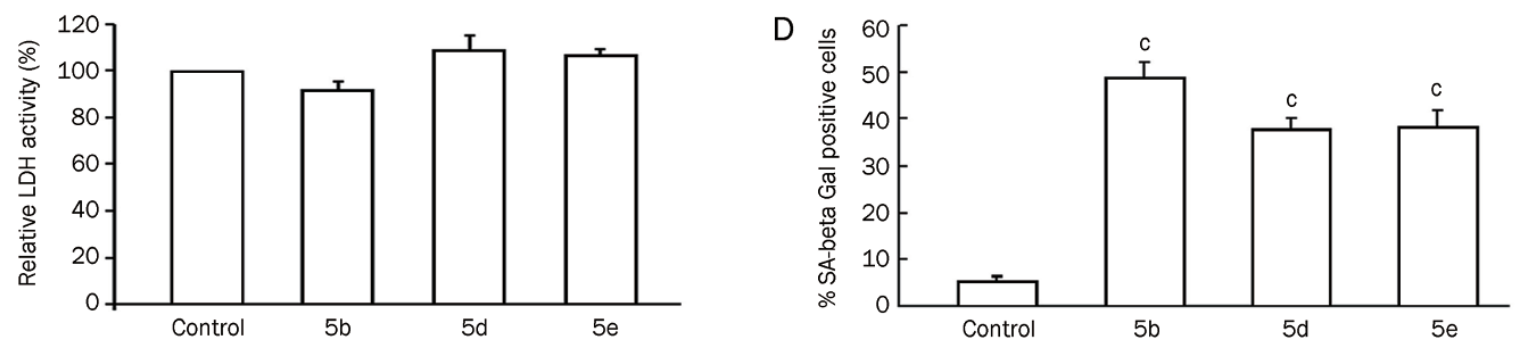

Figure 4. (A) Detection of apoptosis by Hoechst 33258 staining of A549 cells treated with $5 \mathrm{~b}$, $5 \mathrm{~d}$, and $5 \mathrm{e}(80 \mu \mathrm{mol} / \mathrm{L})$ for $48 \mathrm{~h}(\mathrm{n}=3)$. Microscopic photographs ( $\times 400$ ) were taken under a fluorescence microscope (Nikon). (B) Senescence-associated beta-galactosidase (SA- $\beta$-Gal) activity in A549 cells treated with $5 \mathrm{~b}, 5 \mathrm{~d}$, and $5 \mathrm{e}(80 \mu \mathrm{mol} / \mathrm{L})$ for $48 \mathrm{~h}$. Microscopic photographs $(\times 400)$ were taken with a phase contrast microscope (Nikon). (C) Effects of compounds $5 \mathrm{~b}, 5 \mathrm{~d}$, and $5 \mathrm{e}(80 \mu \mathrm{mol} / \mathrm{L})$ on the release of $\mathrm{LDH}$ from A549 cells at $48 \mathrm{~h}(P>0.05$ vs control group, $n=3)$. (D) Percentage of SA$\beta$-Gal-positive cells ( ${ }^{\mathrm{C}} P<0.01$ vs control group; $n=3$ ).

\section{$5 \mathrm{~B}$ and $5 \mathrm{D})$.}

ROS can induce senescence via several signaling pathways, the most important of which is the p38 MAP-kinase pathway ${ }^{[38,39]}$. To determine the mechanism by which compounds $5 b, 5 d$, and $5 e$ induce senescence, we examined the p-p38 and p38 levels by Western blotting. As shown in Figure 6, compounds $5 \mathrm{~b}, 5 \mathrm{~d}$, and $5 \mathrm{e}$ promoted $\mathrm{p} 38$ phosphorylation. To further investigate the relationship between ROS and p38 MAP-kinase in compounds 5b-, 5d-, and 5e-induced senescence, we treated A549 cells with N-acetyl-L-cysteine (NAC), an antioxidant and free radical scavenger that reduces ROS levels ${ }^{[40]}$. After incubation with $10 \mathrm{mmol} / \mathrm{L}$ NAC, compounds $5 \mathrm{~b}, 5 \mathrm{~d}$, and $5 \mathrm{e}(80 \mu \mathrm{mol} / \mathrm{L})$ failed to elevate ROS levels (Figure 7A and 7D). Along with the decrease in ROS levels, the MMP returned to its basal level (Figure 7B and 7D). As shown in Figure 7C, compound 5b-, 5d-, and 5e-induced senescence of A549 cells was dramatically suppressed in the presence of NAC. Moreover, NAC also inhibited the induction of p38 phosphorylation in response to these compounds (Figure 8).

\section{Discussion}

Here, we studied the biological effects of several recently synthesized, novel 1-ferrocenyl-2-(5-phenyl-1H-1,2,4-triazol-3ylthio)ethanone derivatives to determine their mechanism of action in A549 cells. Our results revealed that compounds 5b, $5 \mathrm{~d}$, and 5e inhibited growth and induced senescence in A549 lung cancer cells. Tumorigenesis relies on a balance between senescence and immortalization. Senescence is prevalent in pre-malignant tumors, and progression to malignancy requires evading senescence. Recently, it was reported that the activation of senescence may represent a key target for therapeutic intervention and the eradication of cancer ${ }^{[41,42]}$. Nevertheless, for many years, the role of senescence in opposing tumor growth in vivo was underestimated.

Accumulating evidence indicates that senescence plays an important role in the natural physiological response to tumor development ${ }^{[43]}$. Multiple pieces of evidence reveal that signaling events underlying the senescent phenotype, including, but not limited to, invasion, metastasis ${ }^{[44]}$, proliferation ${ }^{[45]}$ 
A

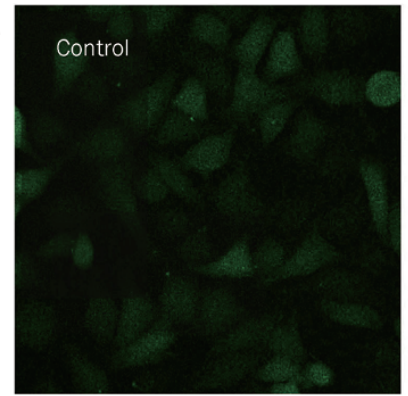

B

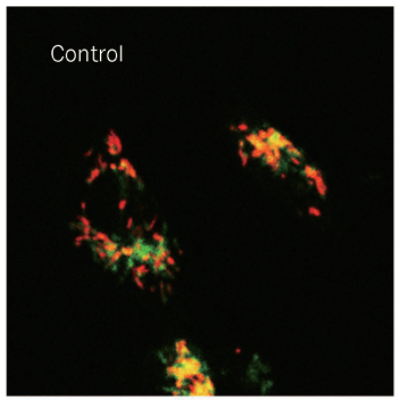

C

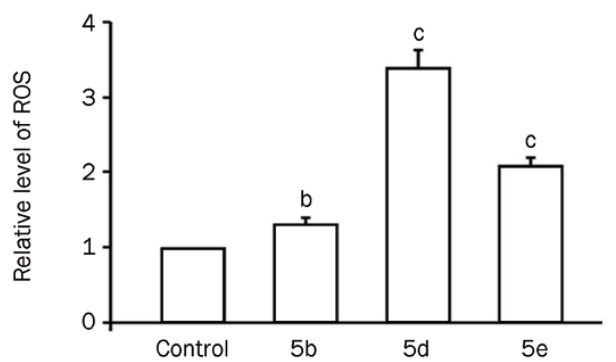

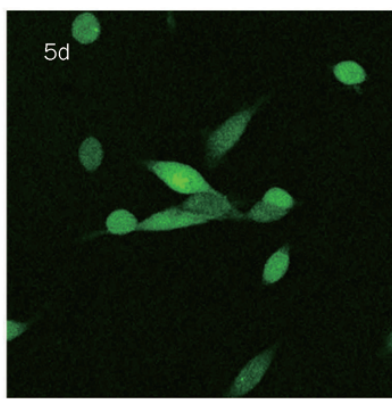
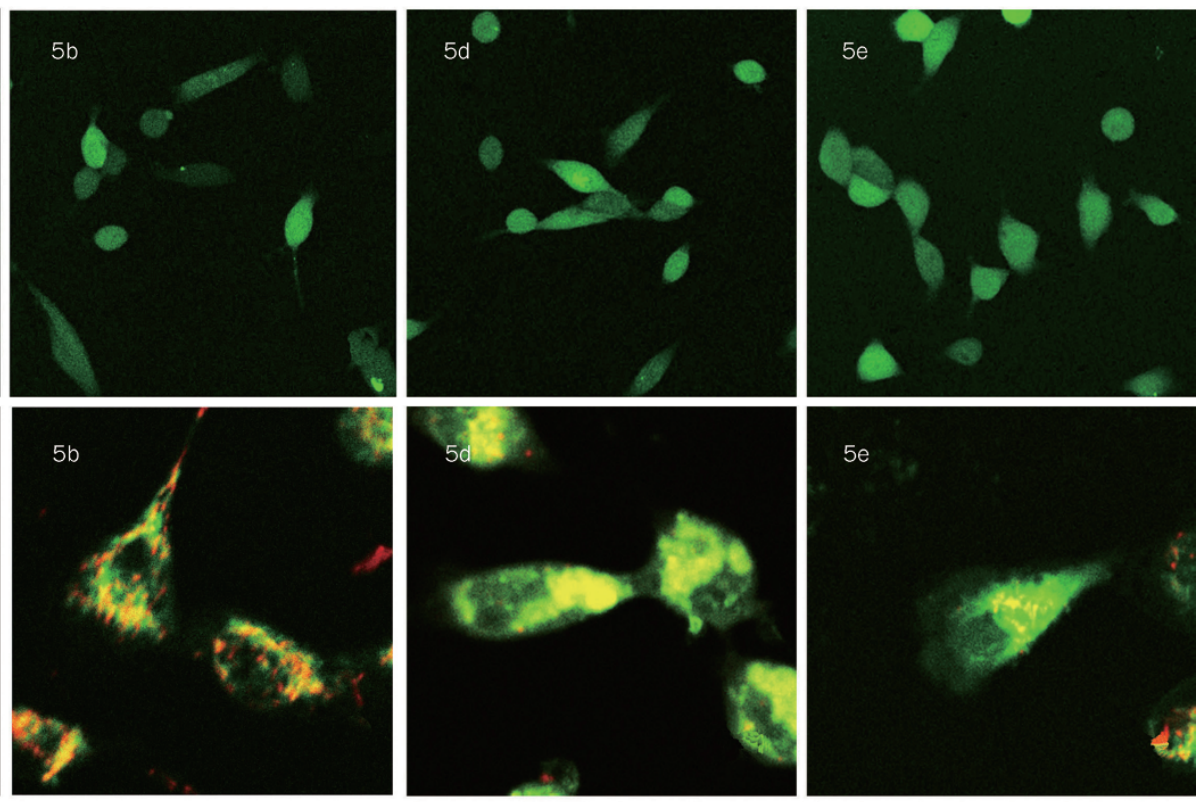

D

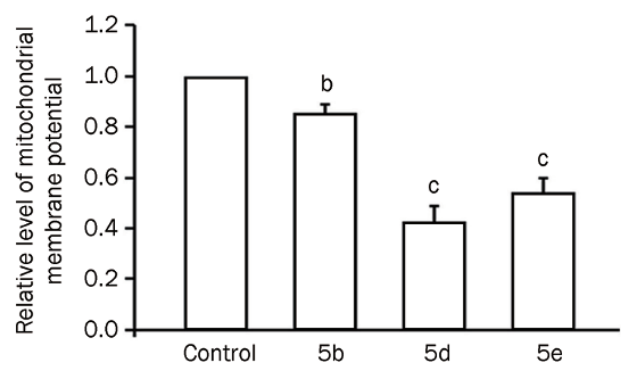

Figure 5. (A) Effects of compounds $5 \mathrm{~b}, 5 \mathrm{~d}$, and $5 \mathrm{e}(80 \mu \mathrm{mol} / \mathrm{L})$ on the level of ROS in $\mathrm{A} 549$ cells at $48 \mathrm{~h}$. Fluorescent micrographs show the relative intensity of ROS. (B) Effects of compounds $5 \mathrm{~b}, 5 \mathrm{~d}$, and $5 \mathrm{e}(80 \mu \mathrm{mol} / \mathrm{L})$ on the mitochondrial membrane potential (MMP) at $48 \mathrm{~h}$. (C) The relative amount of ROS in A549 cells. (D) Relative MMP was quantified as the ratio of red/green fluorescence intensity per cell $\left({ }^{\mathrm{b}} P<0.05\right.$, ${ }^{\mathrm{C}} P<0.01 \mathrm{vs}$ control group; $n=3)$.

A
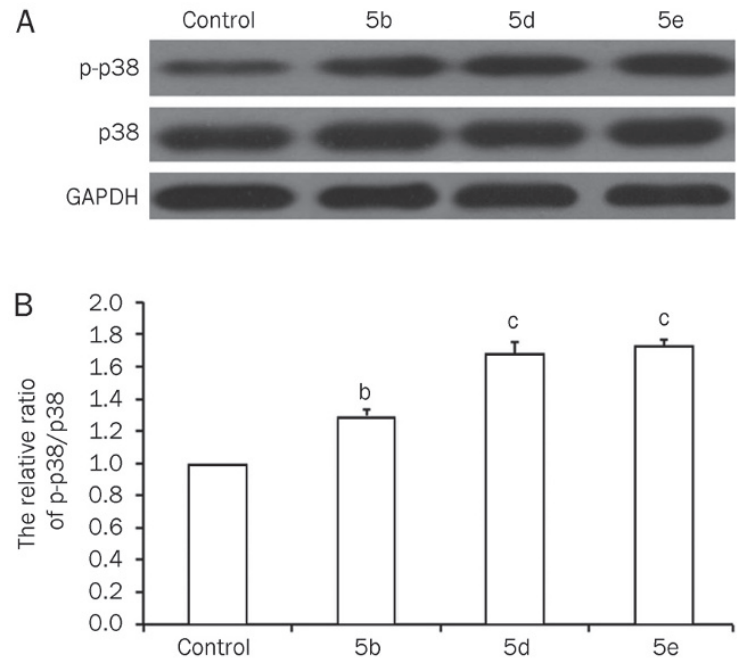

Figure 6. (A) Western blot assay of p-p38 and p38 in A549 cells treated with $5 \mathrm{~b}, 5 \mathrm{~d}$, and $5 \mathrm{e}(80 \mu \mathrm{mol} / \mathrm{L})$ for $48 \mathrm{~h}$. (B) The relative ratio of $\mathrm{p}-\mathrm{p} 38 /$ p38 $\left({ }^{b} P<0.05,{ }^{c} P<0.01\right.$ vs control group; $\left.n=3\right)$. immortalization ${ }^{[46]}$ and immune modulation ${ }^{[47]}$, are critical for tumorigenesis. Nardella and Cairney et al proposed that these intrinsic senescence pathways can be used to specifically enhance senescence for the potential eradication of disease through targeted approaches ${ }^{[43,47]}$. Therefore, cancer cell senescence has become a new frontier for drug development. Our results show that compounds $5 \mathrm{~b}, 5 \mathrm{~d}$ and $5 \mathrm{e}$ inhibit growth by inducing a strong $\mathrm{G}_{1}$-phase arrest and senescence in lung cancer A549 cells. These data suggest that these novel ferrocenyl derivatives represent useful tools for further investigating the role of cellular senescence and developing drugs for cancer therapy.

Since 1956, when the free radical theory of aging was proposed $^{[48]}$, numerous cell culture, invertebrate, and mammalian models have provided support for this theory ${ }^{[49]}$, which suggests that intracellular ROS are the main reason for cellular senescence. ROS are a natural byproduct of normal oxygen metabolism, and they play important roles in the signaling of cellular senescence. The main metabolic source of ROS is the mitochondrial electron-transport chain, and the accumulation 

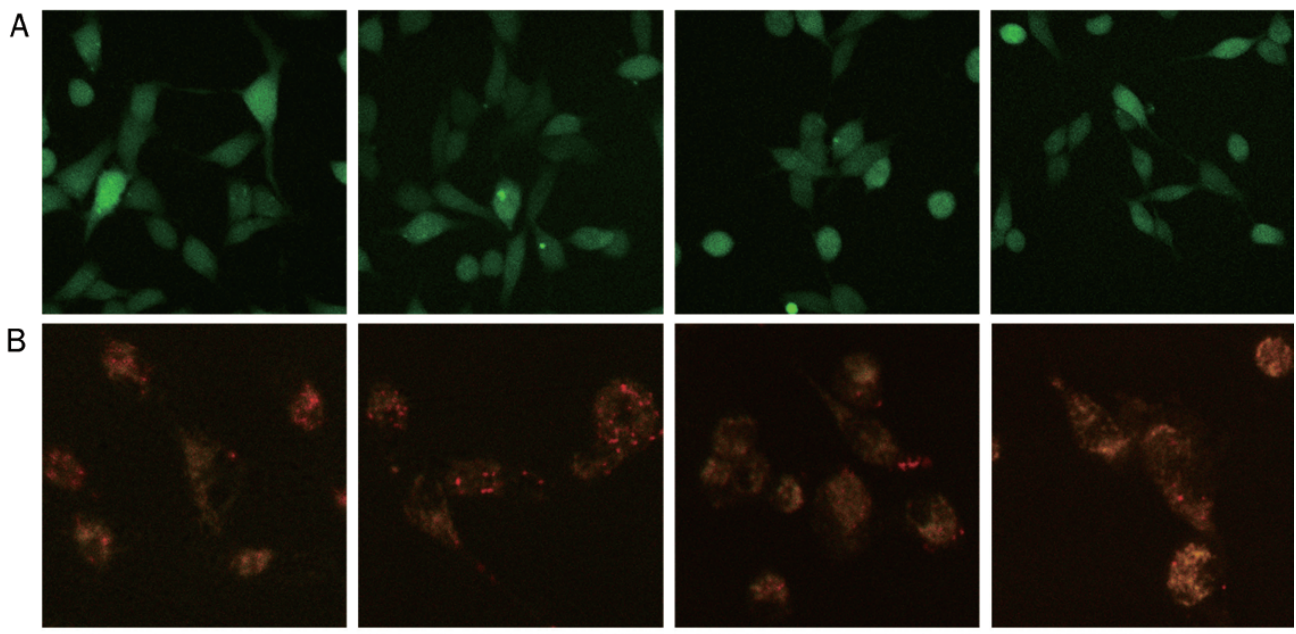

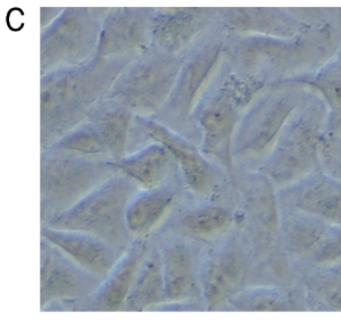

Control

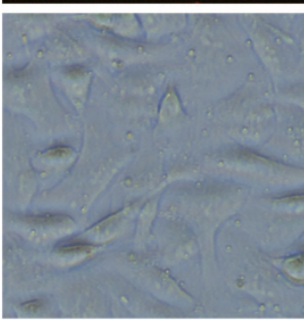

$5 b+N A C$

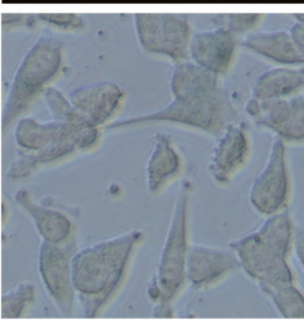

$5 d+N A C$

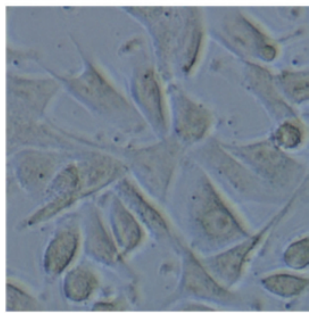

$5 e+N A C$
D

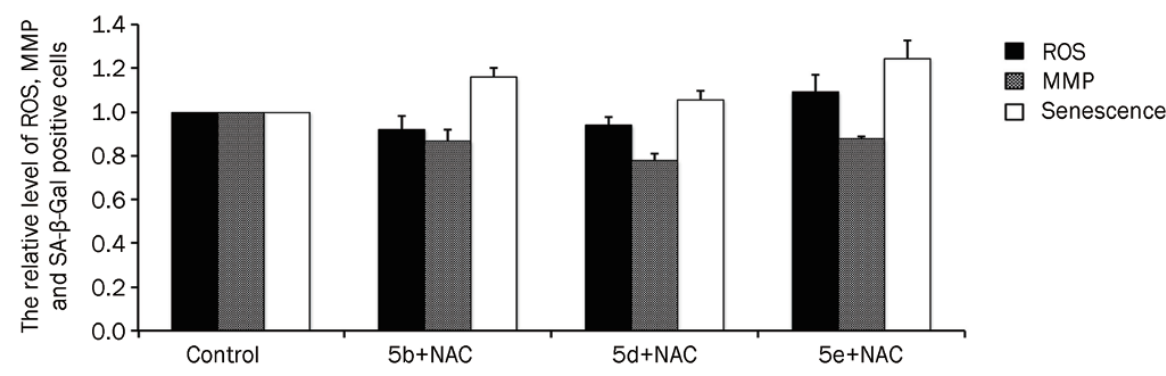

Figure 7. Forty-eight hour treatment with compounds $5 \mathrm{~b}, 5 \mathrm{~d}$, and $5 \mathrm{e}$ (80 $\mu \mathrm{mol} / \mathrm{L})$ failed to increase ROS (A), reduce the level of $M M P(B)$, or induce senescence $(C)$ in the presence of NAC (10 mmol/L). Microscopic photographs $(\times 400)$ were taken with a phase contrast microscope (Nikon). (D) There was no difference in the relative quantity of ROS, MMP and SA- $\beta$-Gal positive cells in the treated group compared to the control group ( $P>0.05$ vs control group; $n=3$ ).
A

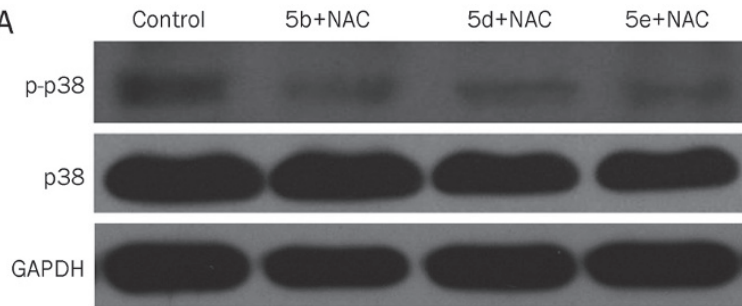

B

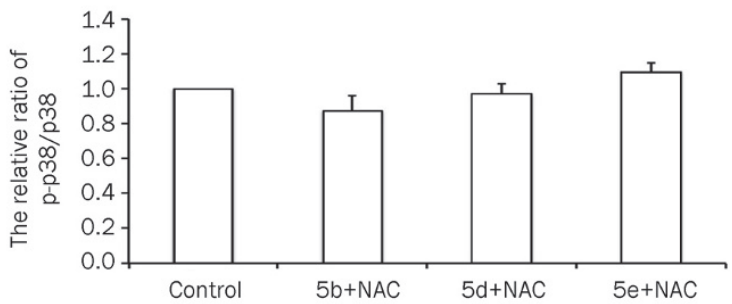

Figure 8 . The ability of compounds $5 b, 5 d$, and $5 e(80 \mu \mathrm{mol} / \mathrm{L})$ to promote p38 phosphorylation was inhibited by NAC $(10 \mathrm{mmol} / \mathrm{L})$. (A) Western blot assay of p-p38 and p38. (B) There was no difference between the ratio of p-p38/p38 in the treatment group compared to the control group $(P>0.05$ vs control group; $n=3$ ). of intracellular ROS can cause mitochondrial dysfunction, resulting in reduced $\mathrm{MMP}^{[49,50]}$. The accumulation of mitochondrial ROS increases the vulnerability of the mitochondrial genome, which impairs mitochondrial energy metabolism, leading to mitochondrial dysfunction ${ }^{[51]}$. In addition, it is known that changes in the intracellular ROS levels can induce biochemical signaling processes that control basic cellular functions, including senescence ${ }^{[52]}$. MMP is an important mediator of key cellular processes, and it is also a critical regulator of cellular senescence. MMP is also a highly sensitive indicator of the energetic state of mitochondria and the health of cells ${ }^{[53]}$.

Our results show that elevated intracellular ROS decreased MMP, and the phosphorylation of p38 may be responsible for compound 5b-, 5d- and 5e-induced senescence in A549 cells. Taken together, our findings suggest that compounds $5 \mathrm{~b}, 5 \mathrm{~d}$ and 5 e may be useful tools for investigating cellular senescence and promoting senescence as a cancer therapy.

\section{Acknowledgements}

This work was financially supported by the National Natu- 
ral Science Foundation of China (№ 31270877, 90813022, 20972088, 31070735, and 81021001) and the National 973 Research Project (№ 2011CB503906).

\section{Author contribution}

Jun-ying MIAO and Bao-xiang ZHAO designed the research. Ying LI, Han-lin MA, Lei HAN, and Wei-yong LIU performed the research. Shang-li ZHANG analyzed the data. Han-lin MA and Lei HAN wrote the paper.

\section{References}

1 Jemal A, Siegel R, Ward E, Hao Y, Xu J, Thun MJ. Cancer statistics, 2009. CA Cancer J Clin 2009; 59: 225-49.

2 Lee ER, Kang YJ, Choi HY, Kang GH, Kim JH, Kim BW, et al. Induction of apoptotic cell death by synthetic naringenin derivatives in human lung epithelial carcinoma A549 cells. Biol Pharm Bull 2007; 30: 2394-8.

3 Kemnitzer W, Jiang S, Wang Y, Kasibhatla S, Crogan-Grundy C, Bubenik M, et al. Discovery of 4 -aryl- ${ }^{4} \mathrm{H}$-chromenes as a new series of apoptosis inducers using a cell- and caspase-based HTS assay. Part 5: modifications of the 2- and 3-positions. Bioorg Med Chem Lett 2008; 18: $603-7$.

4 Hu WP, Yu HS, Chen YR, Tsai YM, Chen YK, Liao CC, et al. Synthesis and biological evaluation of thiobenzanilides as anticancer agents. Bioorg Med Chem 2008; 16: 5295-302.

5 Karabasanagouda T, Adhikari AV, Shetty NS. Synthesis and antimicrobial activities of some novel 1,2,4-triazolo[3,4-b]-1,3,4-thiadiazoles and 1,2,4-triazolo[3,4-b]-1,3,4-thiadiazines carrying thioalkyl and sulphonyl phenoxy moieties. Eur J Med Chem 2007; 42: 521-9.

6 Karegoudar P, Prasad DJ, Ashok M, Mahalinga M, Poojary B, Holla BS. Synthesis, antimicrobial and anti-inflammatory activities of some 1,2,4-triazolo[3,4-b][1,3,4]thiadiazoles and 1,2,4-triazolo[3,4-b] $[1,3,4]$ thiadiazines bearing trichlorophenyl moiety. Eur J Med Chem 2008; 43: 808-15.

7 Demirbas A, Sahin D, Demirbas N, Karaoglu SA. Synthesis of some new 1,3,4-thiadiazol-2-ylmethyl-1,2,4-triazole derivatives and investigation of their antimicrobial activities. Eur J Med Chem 2009; 44: 2896-903.

8 Salgin-Goksen U, Gokhan-Kelekci N, Goktas O, Koysal Y, Kilic $\mathrm{E}$, Isik S, et al. 1-Acylthiosemicarbazides, 1,2,4-triazole-5(4H)thiones, 1,3,4-thiadiazoles and hydrazones containing 5-methyl2-benzoxazolinones: synthesis, analgesic-anti-inflammatory and antimicrobial activities. Bioorg Med Chem 2007; 15: 5738-51.

9 Amir M, Kumar H, Javed SA. Synthesis and pharmacological evaluation of condensed heterocyclic 6-substituted-1,2,4-triazolo[3,4b]-1,3,4-thiadiazole derivatives of naproxen. Bioorg Med Chem Lett 2007; 17: 4504-8.

10 Collin X, Sauleau A, Coulon J. 1,2,4-Triazolo mercapto and aminonitriles as potent antifungal agents. Bioorg Med Chem Lett 2003; 13: 2601-5.

11 Ma Y, Liu R, Gong X, Li Z, Huang Q, Wang H, et al. Synthesis and herbicidal activity of $\mathrm{N}, \mathrm{N}$-diethyl-3-(arylselenonyl)-1H-1,2,4-triazole-1carboxamide. J Agric Food Chem 2006; 54: 7724-8.

12 Cudworth DP, Hegde VB, Yap MC, Guenthenspberger KA, Hamilton CT, Pechacek JT, et al. Structure-activity relationship development of dihaloaryl triazole compounds as insecticides and acaricides. 1. Phenyl thiophen-2-yl triazoles. J Agric Food Chem 2007; 55 : 7517 26.

13 Ouyang X, Chen X, Piatnitski EL, Kiselyov AS, He HY, Mao Y, et al. Synthesis and structure-activity relationships of 1,2,4-triazoles as a novel class of potent tubulin polymerization inhibitors. Bioorg Med Chem Lett 2005; 15: 5154-9.

14 Ibrahim DA. Synthesis and biological evaluation of 3,6-disubstituted $[1,2,4]$ triazolo[3,4-b][1,3,4]thiadiazole derivatives as a novel class of potential anti-tumor agents. Eur J Med Chem 2009; 44: 2776-81.

15 Chabchoub F, Messaad M, Ben Mansour H, Chekir-Ghedira L, Salem M. Synthesis and antigenotoxic activity of some naphtho[2,1-b] pyrano[3,2-e][1,2,4]triazolo[1,5-c]pyrimidine derivatives. Eur J Med Chem 2007; 42: 715-8.

16 Kelly PN, Pretre A, Devoy S, O’Rielly I, Devery R, Goel A, et al. Synthesis, structural characterisation and biological activity of novel $\mathrm{N}$-(ferrocenylmethyl)benzene-carboxamide derivatives. J Organomet Chem 2007; 692: 1327-31.

17 Fouda MFR, Abd-Elzaher MM, Abdelsamaia RA, Labib AA. On the medicinal chemistry of ferrocene. Applied Organomet Chem 2007; 21: 613-25.

18 Zora M, Gormen M. Synthesis of ferrocenyl pyrazoles by the reaction of (2-formyl-1-chlorovinyl)ferrocene with hydrazines. J Organomet Chem 2007; 692: 5026-32.

19 Zora M, Velioglu O. Synthesis of ferrocenyl quinolines. J Organomet Chem 2008; 693: 2159-62.

$20 \mathrm{Yu} \mathrm{HB}$, Shao L, Fang JX. Synthesis and biological activity research of novel ferrocenyl-containing thiazole imine derivatives. J Organomet Chem 2007; 692: 991-6.

21 Mochida T, Shimizu F, Shimizu H, Okazawa K, Sato F, Kuwahara D. Ferrocenylpyrazole - A versatile building block for hydrogen-bonded organometallic supramolecular assemblies. J Organomet Chem 2007; 692: 1834-44.

22 Maity B, Roy M, Chakravarty AR. Ferrocene-conjugated copper(II) dipyridophenazine complex as a multifunctional model nuclease showing DNA cleavage in red light. J Organomet Chem 2008; 693: 1395-9.

23 Liu WY, Xie YS, Zhao BX, Lian S, Lv HS, Gong ZL, et al. The synthesis, X-ray crystal structure and optical properties of novel 1-ferrocenyl-2(3-phenyl-1H-1,2,4-triazol-5-ylthio)ethanone derivatives. Spectrochim Acta A Mol Biomol Spectrosc 2010; 76: 531-6.

24 Fan C, Su H, Zhao J, Zhao B, Zhang S, Miao J. A novel copper complex of salicylaldehyde pyrazole hydrazone induces apoptosis through upregulating integrin beta4 in H322 lung carcinoma cells. Eur J Med Chem 2010; 45: 1438-46.

25 Ding XL, Zhang HY, Qi L, Zhao BX, Lian S, Lv HS, et al. Synthesis of novel pyrazole carboxamide derivatives and discovery of modulators for apoptosis or autophagy in A549 lung cancer cells. Bioorg Med Chem Lett 2009; 19: 5325-8.

26 Zheng LW, Wu LL, Zhao BX, Dong WL, Miao JY. Synthesis of novel substituted pyrazole-5-carbohydrazide hydrazone derivatives and discovery of a potent apoptosis inducer in A549 lung cancer cells. Bioorg Med Chem 2009; 17: 1957-62.

27 Pan XH, Liu X, Zhao BX, Xie YS, Shin DS, Zhang SL, et al. 5-Alkyl-2ferrocenyl-6,7-dihydropyrazolo[1,5-a]pyrazin-4(5H)-one derivatives inhibit growth of lung cancer A549 cell by inducing apoptosis. Bioorg Med Chem 2008; 16: 9093-100.

28 Skulachev VP, Anisimov VN, Antonenko YN, Bakeeva LE, Chernyak BV, Erichev VP, et al. An attempt to prevent senescence: a mitochondrial approach. Biochim Biophys Acta 2009; 1787: 437-61.

29 Saretzki G. Cellular senescence in the development and treatment of cancer. Curr Pharm Des 2010; 16: 79-100.

30 Price $\mathrm{P}$, McMillan TJ. Use of the tetrazolium assay in measuring the response of human tumor cells to ionizing radiation. Cancer Res 1990; 50: 1392-6.

31 Litwiniec A, Grzanka A, Helmin-Basa A, Gackowska L, Grzanka D. 
Features of senescence and cell death induced by doxorubicin in A549 cells: organization and level of selected cytoskeletal proteins. J Cancer Res Clin Oncol 2010; 136: 717-36.

32 Smiley ST, Reers M, Mottola-Hartshorn C, Lin M, Chen A, Smith TW, et al. Intracellular heterogeneity in mitochondrial membrane potentials revealed by a J-aggregate-forming lipophilic cation JC-1. Proc NatI Acad Sci U S A 1991; 88: 3671-5.

33 Schulz E, Dopheide J, Schuhmacher S, Thomas SR, Chen K, Daiber A, et al. Suppression of the JNK pathway by induction of a metabolic stress response prevents vascular injury and dysfunction. Circulation 2008; 118: 1347-57.

34 Du AY, Zhao BX, Yin DL, Zhang SL, Miao JY. Discovery of a novel small molecule, 1-ethoxy-3-(3,4-methylenedioxyphenyl)-2-propanol, that induces apoptosis in A549 human lung cancer cells. Bioorg Med Chem 2005; 13: 4176-83.

35 Stewart ZA, Westfall MD, Pietenpol JA. Cell-cycle dysregulation and anticancer therapy. Trends Pharmacol Sci 2003; 24: 139-45.

36 Reddy MV, Mallireddigari MR, Cosenza SC, Pallela VR, Iqbal NM, Robell KA, et al. Design, synthesis, and biological evaluation of (E)styrylbenzylsulfones as novel anticancer agents. J Med Chem 2008; 51: 86-100.

37 Xie YS, Zhao HL, Su H, Zhao BX, Liu JT, Li JK, et al. Synthesis, singlecrystal characterization and preliminary biological evaluation of novel ferrocenyl pyrazolo[1,5-a]pyrazin-4(5H)-one derivatives. Eur J Med Chem 2010; 45: 210-8.

38 Delanian S, Lefaix JL. The radiation-induced fibroatrophic process: therapeutic perspective via the antioxidant pathway. Radiother Oncol 2004; 73: 119-31.

39 Sarsour EH, Kumar MG, Chaudhuri L, Kalen AL, Goswami PC. Redox control of the cell cycle in health and disease. Antioxid Redox Signal 2009; 11: 2985-3011.

40 Chen Y, Xu X, Sheng M, Zhang X, Gu Q, Zheng Z. PRMT-1 and DDAHsinduced ADMA upregulation is involved in ROS- and RAS-mediated diabetic retinopathy. Exp Eye Res 2009; 89: 1028-34.

41 Provinciali M, Cardelli M, Marchegiani F, Pierpaoli E. Impact of cellular senescence in aging and cancer. Curr Pharm Des 2013; 19: 1699709.

42 Collado M, Serrano M. Senescence in tumours: evidence from mice and humans. Nat Rev Cancer 2010; 10: 51-7.

43 Nardella C, Clohessy JG, Alimonti A, Pandolfi PP. Pro-senescence therapy for cancer treatment. Nature Rev Cancer 2011; 11: 503-11.

44 Ansieau S, Bastid J, Doreau A, Morel AP, Bouchet BP, Thomas C, et al. Induction of EMT by twist proteins as a collateral effect of tumorpromoting inactivation of premature senescence. Cancer Cell 2008; 14: 79-89.

45 Majumder PK, Grisanzio C, O'Connell F, Barry M, Brito JM, Xu Q, et al. A prostatic intraepithelial neoplasia-dependent p27 Kip1 checkpoint induces senescence and inhibits cell proliferation and cancer progression. Cancer Cell 2008; 14: 146-55.

46 Feldser DM, Greider CW. Short telomeres limit tumor progression in vivo by inducing senescence. Cancer cell 2007; 11: 461-9.

47 Cairney CJ, Bilsland AE, Evans TR, Roffey J, Bennett DC, Narita M, et al. Cancer cell senescence: a new frontier in drug development. Drug Discov Today 2012; 17: 269-76.

48 Harman D. Aging: a theory based on free radical and radiation chemistry. J Gerontol 1956; 11: 298-300.

49 Balaban RS, Nemoto S, Finkel T. Mitochondria, oxidants, and aging. Cell 2005; 120: 483-95.

50 Beckman KB, Ames BN. The free radical theory of aging matures. Physiol Rev 1998; 78: 547-81.

51 Alpert D, Schwenger P, Han J, Vilcek J. Cell stress and MKK6bmediated p38 MAP kinase activation inhibit tumor necrosis factorinduced IkappaB phosphorylation and NF-kappaB activation. J Biol Chem 1999; 274: 22176-83.

52 Katakura Y. Molecular basis for the cellular senescence program and its application to anticancer therapy. Biosci Biotechnol Biochem 2006; 70: 1076-81.

53 Rothfuss 0, Gasser T, Patenge N. Analysis of differential DNA damage in the mitochondrial genome employing a semi-long run real-time PCR approach. Nucleic Acids Res 2010; 38: e24. 